Please do not remove this page

RMIT

UNIVERSITY

\title{
Workplace sexual harassment at the margins
}

McDonald, Paula; Charlesworth, Sara

https://researchrepository.rmit.edu.au/esploro/outputs/9921862432401341/filesAndLinks?institution=61RMIT_INST\&index=null

McDonald, P., \& Charlesworth, S. (2016). Workplace sexual harassment at the margins. Work, Employment and Society, 30(1), 118-134. https://doi.org/10.1177/0950017014564615

Document Version: Accepted Manuscript

Published Version: https://doi.org/10.1177/0950017014564615

Repository homepage: https://researchrepository.rmit.edu.au

(C) The Author(s)

Downloaded On 2023/04/27 00:17:41 +1000

Please do not remove this page 
Thank you for downloading this document from the RMIT Research Repository.

The RMIT Research Repository is an open access database showcasing the research outputs of RMIT University researchers.

RMIT Research Repository: http://researchbank.rmit.edu.au/

\section{Citation:}

McDonald, P and Charlesworth, S 2015, 'Workplace sexual harassment at the margins', Work, Employment and Society, pp. 1-17.

See this record in the RMIT Research Repository at:

https://researchbank.rmit.edu.au/view/rmit:33610

Version: Accepted Manuscript

Copyright Statement: (c) The Author(s)

Link to Published Version:

http://dx.doi.org/10.1177/0950017014564615 
Work Employment and Society, Published online before print, April 17, 2015,

doi:10.1177/0950017014564615

Paula McDonald (Queensland University of Technology)

Sara Charlesworth (RMIT University)

Workplace sexual harassment at the margins

\begin{abstract}
Men are overwhelmingly responsible for sexual harassment against women in the workplace. However, the literature also points to more atypical manifestations, including sexual harassment by men of other men, and by women of men or other women. This article examines these atypical forms of sexual harassment, drawing on a census of all formal sexual harassment complaints lodged with Australian equal opportunity commissions over a sixmonth period. The analysis reveals some important distinctions and similarities across groups of atypical complaints, as well as between atypical groups and 'classic' sexual harassment complaints where men harass women. The article contributes to the relatively undeveloped literature on these less visible forms of sexual harassment and highlights both theoretical and pragmatic challenges in better understanding workplace sexual harassment 'at the margins'.
\end{abstract}

\title{
Key words
}

Complaint management; discrimination; equal opportunity; workplace sexual harassment 
A vast literature has been generated on the subject of workplace sexual harassment (SH), addressing themes including its prevalence, causes and consequences, and how it might be prevented and redressed. This literature has typically focused on 'classic' forms of SH involving men harassing women. Despite the predominance of this type, the literature also points to other more atypical manifestations, including harassment by men towards other men, and by women towards men or other women. Yet these forms of SH have received relatively little attention.

While prevalence estimates of SH diverge markedly depending on methodological protocols (McDonald, 2012), a recent, representative prevalence survey in Australia revealed that around 25 percent of women and 16 percent of men reported having experienced SH in the workplace in the past five years (Australian Human Rights Commission [AHRC], 2012). The same national survey reported that 29 percent of respondents who experienced $\mathrm{SH}$, indicated it involved same-sex dyads (23\% male-to-male; 6\% female-to-female) and an additional 14 percent indicated female-to-male SH (AHRC, 2012). Research elsewhere also suggests that while the predominant form of SH involves a male harasser and a female target, men are the targets of SH far more commonly than typically assumed by researchers, the popular media or the community at large (e.g., Aggarwal and Gupta, 2000; Illies et al., 2003). Men report SH by men more often than by women, while women only rarely report being harassed by other women (Berdahl et al., 1996; Dubois et al., 1998; Magley et al., 1999; Waldo et al., 1998). Despite an increasing recognition of SH 'at the margins', studies of SH experienced by men are relatively few and those that do include men in their samples often aggregate the data, treating men's experiences of SH as identical to women’s (Magley et al., 1999). The empirical examination of SH perpetrated by women is even more neglected.

In most industrialised countries, workplace $\mathrm{SH}$ is legally proscribed in antidiscrimination laws (McCann, 2005), which typically establish a mechanism whereby 
individual workers may lodge a formal complaint and seek acknowledgment or redress for the SH through a conciliation process. In the United States, SH is legally constructed as a form of sex discrimination, which may also incorporate sex- (or gender)-based slurs and harassment (Forell, 2006: 155). In contrast, SH in other countries such as Australia, Canada and the United Kingdom (UK) is legally defined as requiring unwelcome conduct of a 'sexual nature', with sex and gender-based harassment covered by the separate legal proscription of sex discrimination or discrimination on grounds such as sexual orientation. In practice, however, legal distinctions between SH and sex-based harassment in most jurisdictions are often blurred or unimportant, in that allegations of both often form part of the same complaint and both are treated as discrimination in the complaint handling process. While legal distinctions between SH and sex-based harassment may arise in the small minority of cases that proceed to tribunals and courts, in case law in many countries, sex-based insults and harassment have been constructed as part of a broader pattern of inappropriate sexual conduct (e.g., AHRC, 2011: 49).

This article contributes to better understanding the extent and nature of atypical SH complaints. We foreground the empirical analysis with a number of overlapping theoretical perspectives that have been posed to help explain these more unusual manifestations. We then draw on detailed quantitative and qualitative information contained in files of $282 \mathrm{SH}$ complaints lodged in all nine Australian federal, state and territory equal opportunity commissions ${ }^{1}$ in a six-month period. The data includes detailed information collected from each hard copy file about $\mathrm{SH}$ which occurred in a diverse range of actual workplace settings. To the best of our knowledge, the study is unique in the sense that it draws on a census of SH complaints in a national setting, allowing for a systematic examination of both the relative frequency with which formal complaints of atypical and 'classic' forms of SH are made, as 
well as comparisons of specific characteristics and circumstances across the four groups of interest.

\section{Workplace sexual harassment: Explanatory perspectives}

Early theoretical explanations for SH focused on what was seen as the most prevalent form of SH: by a male boss toward a female subordinate. These perspectives included the naturalbiological model, which proposes that $\mathrm{SH}$ results from natural and inevitable feelings of sexual desire expressed by men toward women, and sex role spillover theory, which suggests that $\mathrm{SH}$ is a form of socio-sexual behaviour at work that results from the roles of men as sexual agents and women as sexual objects, particularly in numerically skewed work environments (e.g., Berdahl, 2007). Both models have been heavily critiqued. The naturalbiological model is dismissed on the basis that it denies $\mathrm{SH}$ is actually discrimination and lacks rigour in explaining same-sex harassment and harassment of lower status men by women in positions of power (Foote and Goodman-Delahunty, 2005). Sex role spillover theory has been critiqued because of its use of occupational sex ratios as proxies for sex roles, such as equating feminine roles (e.g., nurturing, sexy) with the job (e.g., nurses, waitresses) in female-dominated work contexts, as well as its emphasis on women's gender, rather than their job status, in male-dominated environments (Gutek, 1985; Welsh, 1999).

In contrast, feminist theoretical perspectives are underpinned by concepts of power. Such perspectives suggest that SH arises from men's economic power over women which enables them to exploit and coerce women sexually (MacKinnon, 1979; Zalk, 1990). However, Brant and Too (1994) argue that the power model of SH ignores extensive evidence suggesting that harassment from peers or juniors may be more common than harassment by individuals in positions of authority. In attempting to reconcile the power 
model of SH with studies suggesting that co-workers are commonly identified as harassers (e.g., AHRC, 2012), Samuels (2003) has argued that a feminist perspective views power not as an unmediated force but as an amalgam of ideological influences both within and outside the workplace, rendering women, even if in more senior positions, more vulnerable (see also Wajcman, 1998).

These explanations for SH have been useful in explaining SH by men against women. In contrast, and drawing on Butler's (1990) notion of the heterosexual matrix, Epstein (1997: 165) attempts to explain same-sex SH by arguing that SH is 'heterosexist', in that heterosexuality is rendered compulsory through the punishment of deviance from heterosexual norms. Generally applied, the heterosexist perspective suggests that where business is organised according to dominant masculine norms, workers are schooled into gender-appropriate behaviours, where individuals, and men in particular, are punished for deviating from their prescribed gender role, via homophobic, antigay biases and gender hostility (Epstein, 1997; Knights and Tullberg, 2011; Pryor and Whalen, 1997). The expression of such hostility 'becomes a powerful means to keep discipline and to sustain male bonding in ways that help to secure a stable masculine identity’ (Knights \& Tullberg 2011 389). This framing appears to provide powerful explanatory value for the SH of men by other men.

Experimental vignette research, which addresses perceptions of SH according to the gender of the target, provides further support for heterosexist explanations of SH where the target is a man. Studies have found that men who complain of SH are believed less, liked less and punished more than women who complain, purportedly because schema-driven expectancies of observers lead to negative evaluations of individuals who do not conform to expected gender roles (Madera et al., 2007). That is, men who report SH effectively violate expectations of what men usually do and are consequently disbelieved or criticised. Similarly, 
perpetrators of same-sex SH are evaluated more negatively than those involved with opposite-sex cases (DeSouza and Solberg, 2004; Wayne et al., 2001).

Organisational perspectives on SH can also help explain the persistence of different manifestations of workplace SH. Fitzgerald and colleagues, for example, suggest that $\mathrm{SH}$ is largely attributed to two situational characteristics: organisational context, which is the extent to which the organisational climate tolerates $\mathrm{SH}$; and job gender context, which refers to the gendered nature of the individual's work group (Fitzgerald et al., 1997; Fitzgerald et al., 1995). Job gender context in particular has been taken up subsequently to explain both typical forms of SH and also male-to-male SH. For example, Cleveland et al. (2005) describe a blurring of different forms of destructive, gender-based conduct in some workplaces which mark them as masculinised spaces, reinforcing and perpetuating discrimination and harassment in socially acceptable ways. In explaining organisational factors contributing to male-to-male SH in particular, Lee (2000) similarly suggested that the SH of men is often structured by male-male hierarchies of power. Numerous studies in United States’ military settings in particular have explored the dynamics of $\mathrm{SH}$, hazing and sexual assault by men (e.g., Fitzgerald et al., 1999; Skinner et al., 2000; Street et al., 2007).

While no parallel research appears to have examined the specific contexts in which SH by women might occur, organisational perspectives on the 'doing' of gender in the workplace - the performance of masculinity and femininity (see Pullen and Knights 2007) - may shed some light on the ways in which gender and hierarchy may interact where women sexually harass others. Indeed, the consideration of both gender as well as hierarchically-based job roles in the context of particular organizational settings usefully extends more simplistic notions of occupational sex ratios outlined in sex-role spillover theory. 
Wajcman (1998: 113) for example, argues that normative notions of management as masculine may encourage female managers to adopt the sexualised banter used routinely in an attempt to maintain authority and assert their status as managers (see also Pullen and Knights 2007). This perspective may explain SH of junior female employees by senior women. The need to 'fit in' with the dominant gender culture has also been identified in studies of women in non-traditional jobs (e.g., Powell et al 2012), which may lead, in some circumstances, to the tolerance of and collusion in sexually harassing behaviours of coworkers.

The research reported above has yielded significant insights into the prevalence of SH in different work settings, how SH is perceived by those who witness it, and its underlying causes. Our study extends this scholarship in several ways. First, the study examines male-tomale SH in a range of employment contexts outside of military settings where the majority of research examining this particular manifestation of $\mathrm{SH}$ has been undertaken. Second, the study explores the under-examined phenomenon of SH by women (Foote and GoodmanDelahunty, 2005). Third, the analysis allows for an explicit comparison of a large group of complaints of 'classic' SH where men harassed women, with three groups of atypical complaints which were lodged in the same jurisdictions in the same time-frame. Fourth, in contrast to experimental research which utilises written vignettes to ask participants how they would respond in a given scenario, the current study reveals several important yet neglected dimensions of SH in real workplaces, including job-related and personal consequences.

\section{Methods}

The data comprised quantitative and qualitative information contained in all 282 formal complaints of SH lodged in the area of employment in the six-month period from 1 July 2009 
to 31 December 2009 in the nine federal, state and territory equal opportunity commissions in Australia. In addition to educative, compliance and policy development functions, one of the main roles of these bodies (similar to the Advisory, Conciliation and Arbitration Service in the UK and the Equal Employment Opportunity Commission in the US) is to resolve, via conciliation, complaints of discrimination under relevant federal, state or territory laws. Routinely aggregated data related to complaints of discrimination in Australia are very limited and our data collection process involved a rigorous coding of detailed information contained in hard copy complaint files held by the equal opportunity commissions on a 40item pro forma developed for the project. ${ }^{2}$ De-identified qualitative excerpts, which were available in the original complaint form and subsequent updates submitted by the complainant, were also recorded. Examples from these excerpts, and how the complaint process concluded (e.g., settlement amount, referral to tribunal) are used to illustrate the quantitative findings.

We compared four groups of SH complaints: male complainants who alleged SH by men $(\mathrm{N}=31)$, male complainants who alleged SH by women $(\mathrm{N}=14)$, female complainants who alleged SH by women $(\mathrm{N}=16)$, and a much larger comparison group of typical or classic complaints comprising female complainants who alleged SH by men $(\mathrm{N}=221)$. Comparison was made across characteristics including the hierarchical relationship of the complainant and alleged harasser, whether the SH involved physical and/or non-physical harassment, and the employment and personal impacts of the conduct.

There were three main limitations of the data and our subsequent analysis. First, our three 'atypical' harassment groups were much smaller than the group of 'classic' SH complaints. However, since our data is drawn from a census of all SH complaints lodged in Australian in the study time period, these differences reflected the actual prevalence of these particular forms of complaints in the six month time frame, rather than any methodological 
weakness. Second, we aggregated our cross-jurisdictional data for reasons of confidentiality and because the number of complaints lodged in smaller state and territory equal opportunity commissions were significantly fewer. Hence, the number of complaints across groups may not precisely reflect the same distribution of complaints in any one commission. Third, some socio-demographic data such as age and country of birth are not routinely available on commission files, thereby limiting the examination of differences between groups on these characteristics. Missing data in other characteristics we examined was minimal but we report valid percentages to account for this. Notwithstanding these limitations, the scope and variety of different occupational and industry contexts in which the complaints arose and the richness of detail available in the files, allowed for valuable insights into the characteristics of $\mathrm{SH}$ for the three atypical groups of interest, and in comparison to the more typical form which dominates empirical studies and, arguably, community understandings of SH.

\section{Findings}

\section{Sex of complainants and harassers}

Sex data of both the complainant and harasser (see Table 1) showed that overall, the vast majority (252; 89\%) of alleged harassers were male, compared to 30 (11\%) females. Of the 45 male complainants, 31 (69\%) alleged they were harassed by a man and 14 (31\%) alleged they were harassed by a woman. Hence, 11 percent of complaints overall were alleged against a person of the same sex. Consistent with previous research (e.g., AHRC, 2012; DuBois et al., 1998; Stockdale et al., 1999) men were more likely to be alleged harassers and experience same-sex SH than women.

Sixteen (6\%) female complainants alleged they were harassed by a woman, with four of these alleging harassment by two different harassers: three by one man and one woman, and 
the fourth by two women. The complaints involving both female and male harassers were retained in the female-to-female group for quantitative analysis with a focus on the conduct of the female harasser in the textual accounts. An example was a sales worker in a retail store aged in her 40s who alleged that her male co-worker repeatedly made highly offensive sexualised comments, rubbed himself against her and talked about sex. She also alleged that her female manager called her a 'dumb blonde', a 'slut' and told her to 'stop being a "bitch”' This example illustrates that SH complaints sometimes include both explicitly sexual conduct and sex-based slurs and also that where a complainant alleges SH by both a man and a woman, the conduct of each harasser may be distinct.

$<$ Insert Table 1 about here $>$

\section{Hierarchical relationship between complainants and harassers}

As shown in Table 2, the majority of complaints in all four groups were lodged against an alleged harasser who was employed in a more senior position to the complainant. However, this trend was more marked for the female-to-female category, where 15 of the 16 complaints were lodged against a manager/supervisor, and only one against a co-worker. The issue of hierarchical power was tangible in complaints alleged against supervisors in all groups, such as a male complainant who worked for a non-for-profit community organisation who alleged that his female manager asked him to lift up his shirt and show her his muscles as well as shouting at him and humiliating him in front of co-workers. Another complainant, who was a public administration employee working in a remote geographic location, alleged SH against her female manager, which included claims that the manager used highly offensive language and taunted her about her partner being in a sexual relationship with the manager's sister. 
The complainant described living in fear of her manager and being careful not to cause unintended offence as she was wary of retribution. The complainant felt forced to leave her job, which meant leaving the remote location with her family. Her complaint was subsequently found by the commission to be 'unconciliable' and ultimately referred to a tribunal.

In contrast to female-to-female complaints, which were nearly always alleged against someone more senior, around one quarter of both male-to-male, and female-to-male complaints involved allegations against a peer co-worker. One male finance sector professional, for example, alleged his female co-worker repeatedly stated she was 'interested in him', queried whether 'he had a big dick', asked him back to her house, and emailed and called him. Another example of allegations against a co-worker involved a male machinery operator in the retail sector who alleged his male co-worker called him 'princess', told him to ‘toughen up’ and 'get a tiara', and that he would rape him. This complaint settled for $\$ 5,000$, a written apology from the harasser and an agreement from the organisation to review their discrimination policies and training.

Complaints of alleged harassment by external contractors were few and only evident in the typical male-to-female group. Although harassment by clients/customers has been receiving increasing attention in the literature (see Yagil, 2008 for a review) and constituted around nine percent of workplace SH reported in a recent Australian prevalence study (AHRC, 2012), there were no cases of alleged SH complaints against customers in our complaint population. This suggests that complaints of SH by contractors and customers, unlike co-workers and supervisors, rarely escalate beyond the workplace to equal opportunity commissions. 
$<$ Insert Table 2 about here $>$

\section{Nature of the alleged sexual harassment}

The descriptive accounts in each complaint were coded according to the specific type(s) of SH alleged. These categories were then aggregated to identify whether the conduct involved (1) physical SH only, (2) non-physical SH only, or (3) both physical and non-physical SH. The vast majority of all complainants reported some form of non-physical treatment. Sexually suggestive comments/offensive jokes was the most frequently reported category of non-physical SH in all groups. An example in the female-to-female group was a graduate lawyer who worked in scientific and technical services, who alleged her supervisor had spread rumours about her that they had slept together and that she called her a 'slut' and a 'bitch'. The complaint was referred to conciliation but did not settle. An example of sexually suggestive comments/jokes in the male-to-male group was a casino worker who alleged he had been bullied by his co-workers about his sexual orientation. They had asked him how often he masturbated and if he was a virgin, and whether he was trying to hide the fact that he was really gay. This complainant failed his three-month probation, allegedly due to anxiety and stress, and was dismissed. The complaint settled for around \$3,000.

Other non-physical conduct reported by almost one third of typical SH complainants included intrusive questions about private life or physical appearance, whereas this conduct was only reported by around one in six complainants in the three atypical groups. An example in the male-to-male group was a clerical worker in a real estate business who alleged his male employer asked him questions about his sexuality and made sexual comments about his appearance. The complaint settled for $\$ 8,500$ with a written statement of regret. 
Technology-based SH involving sexually explicit emails or SMS messages was also frequently reported, especially in the typical SH group (one in four complaints) and male-tomale group (one in five) but was evident in only one of the 14 female-to-male complaints. An example in the male-to-male group was an information technology systems administrator who alleged his male supervisor told him he was gay after he complained about pictures of naked men on the supervisor's computer wallpaper. The complainant left the company and the complaint did not settle.

As Table 3 shows, reports of ‘non-physical SH only’ occurred frequently across all groups. The most serious example in the female-to-female group involved a commercial laundry worker. She alleged that her supervisor would repeatedly 'rub, slap, tickle and shimmer her breasts, blow kisses and make cruel jokes about sex and discuss her sex life' and that this had endured for nearly a year. The complainant had resigned before lodging the complaint, which settled in conciliation for $\$ 4,250$ and the provision of an employment reference.

$<$ Insert Table 3 about here>

The most frequent form of physical harassment reported by 40 percent of the male-to-female group and around a third of the female-to-female group was unwelcome touching, hugging, cornering or kissing. One such complaint in the female-to-male group involved a sales worker in a retail store who alleged a once-off incident where his female supervisor had arranged a 'group hug’ after a performance management meeting, and that she had pushed herself intimately against him. Another example in the male-to-male group involved a transport worker who alleged his male co-worker put his finger down the back of his pants 
and touched his bottom with a stick, in addition to offensive homophobic remarks including 'what is wrong with you bitch?' This complaint was declined by the relevant commission on the basis that it was out of time. An example of physical SH in the female-to-female group was a sales worker who reported that her female supervisor 'rubbed her breasts against her' and also engaged in a range of non-physical conduct including putting her hands down her own pants, lifting up her top and talking about sex. This complaint was referred to a conciliation conference but did not settle.

None of the complainants in the female-to-female group reported sexual assault. However, this type of SH, which effectively constitutes a criminal act, was reported by a total of 17 individuals in the overall sample, including two men who alleged SH by men and an additional two men who alleged SH by a woman. An example in the male-to-male group was an apprentice who alleged that a new male manager and three of his male co-workers entered a change room, pulled his pants off, put grease between his buttocks and took photos for 10 minutes with a mobile phone. A senior manager who became aware of the incident reported it to the police. The complainant reported feeling extremely violated and went on long-term sick leave. The complaint settled for $\$ 30,000$.

\section{Reported work and non-work consequences of SH for complainants}

When looking at the reported consequences of the SH for the complainants (see Table 4), it was clear that SH frequently resulted in job loss, either through dismissal/redundancy which was instigated by the employer, or forced resignation. Forced resignation resulted from a deterioration of the workplace relationship to the point where the complainant felt they had no choice but to resign. Job loss was evident in one in three complaints in the male-to-male group and more than half of the complaints in the other three groups. An example in the 
female-to-female group was a clerical worker in a food services organisation who alleged that her female supervisor exposed her to pornography via the work computer and that she walked around the workplace in a bikini. She claimed she was fired after lodging a complaint through organisational channels. The complaint was referred to conciliation but did not settle. A further one in six complainants in the male-to-male, and male-to-female groups indicated they were on workers' compensation, sick or stress leave at the time the complaint was lodged, indicating that although the contract of employment remained intact, the employment relationship was tenuous.

A large number of complainants claimed that their workplace and personal relationships were affected by the SH they experienced. This was especially the case in the same-sex groups, with more than half of these complainants reporting this outcome. An example was a male truck driver who reported he was harassed by a male co-worker and who, as a consequence, experienced depression, trauma and strained personal relationships. The complaint settled for $\$ 5,000$ with a written apology and an assurance that the company would review their discrimination and SH policies and training.

In contrast to the other three groups, negative effects on workplace relationships were reported in only two cases in the female-to-male group. Similarly, many of the consequences outside the workplace for the male complainants in this group - including the impact on relationships with partner, family and friends; impact on health and wellbeing; and individual distress/offence - were reported only around half as frequently as for the remaining three groups. As outlined in the Discussion, this suggests female-to-male SH may have a lesser overall impact on the male target than classic or same-sex SH.

$<$ Insert Table 4 about here $>$ 
We explored the issue of workplace relationships further by examining the complainant's employment status at the time the SH complaint was lodged with the equal opportunity commission. Supporting the work-related outcomes reported above and as Table 5 shows, with the exception of the male-to-male group, around two-thirds of complainants named the employer respondent as a former employer, indicating that the employment relationship had broken down prior to the complaint being lodged. An example was a male complainant who worked in a wholesale distribution company who alleged that a female co-worker had propositioned him for sex and had sent him sexually explicit emails, including pictures of naked women and men in g-strings. His employment was terminated after notifying management of the harassment.

The high rates of employment breakdown evident in the data provides further direct evidence of the damaging consequences of SH to workplace relationships and dynamics that has been reported in previous scholarship, including reduced morale and motivation of employees, tardiness and absenteeism, and reduced productivity (EEOC, 2005; Fitzgerald et al., 1997; Willness et al., 2007). Male-to-male SH complainants were more likely than not to have remained in their jobs at least until the complaint was lodged. This might indicate these complainants felt less concerned about retaliation for making a complaint.

$<$ Insert Table 5 about here>

\section{Complaint process and outcomes}

Female-to-male complaints were less likely to settle than other groups. Nine of the 14 (64\%) complaints in this group did not settle, but were rather declined, dismissed or assessed as 
having no prospect of conciliation by the relevant commission, or they lapsed or were withdrawn by the complainant. This was in contrast to complaints that did not settle in the other three groups: 16 of 31 (52\%) male-to-male complaints, 110 of 211 (50\%) of male-tofemale complaints, and nine of 16 (56\%) female-to-female complaints. While small numbers in the three atypical groups makes conclusions about the likelihood of settlement in other jurisdictions tentative, the differences suggest that allegations of SH by men against women may be more difficult to resolve.

One example illustrating these difficulties in the female-to-male group was a higher education lecturer who alleged a female senior co-worker 'sat very close to him, deliberately showing her exposed cleavage'. This complaint was declined by the relevant commission as 'lacking in substance.' Another example involved a male clerical worker in the financial services industry who alleged his female supervisor described how she had become pregnant, citing inappropriate sexual remarks. This complaint was accepted by the relevant commission but withdrawn prior to a conciliation conference.

\section{Discussion}

The laws which prohibit sexual harassment are expressed in gender-neutral terms and provide a complaint mechanism not only for women who are sexually harassed by men, but also for SH that arises in other sex dyads. This article compared the characteristics of SH complaints provided for under such legislation, including three groups of atypical complaints reported to all Australian equal opportunity commissions in a six-month period, with a larger group of 'classic' SH reported by women alleging SH by men. The study supports some lines of previous research in the under-studied area of same-sex and female perpetrated SH and also reveals new insights. 
The relative frequencies of different manifestations of $\mathrm{SH}$ are consistent with previous work showing that when men report SH they are more likely to allege SH by other men, rather than by women (Waldo et al., 1998). However, by examining complaints lodged in all jurisdictions in a national setting in a particular time period, the study provides a precise estimate of this trend, showing that men are more than twice as likely to name other men, compared to women, as harassers.

The findings also provide support for the idea that men perceive not only unwanted sexual attention and sexual coercion as $\mathrm{SH}$, but also the enforcement of the traditional heterosexual male gender role (Berdahl et al., 1996). Indeed, many of the experiences described by complainants in the male-to-male group were characterised by taunts about apparently unmasculine conduct and appearance, and insinuations that the complainants were gay. One explanation for this conduct is a power-sex association, whereby (male) harassers, who would usually prey upon vulnerable women because it arouses their power concept, may resort, in some circumstances, to the harassment of vulnerable males in order to activate the power concept (Bargh and Raymond, 1995; Lee, 2000). Indeed, the scenarios described in the complaints suggest that men who do not conform to dominant standards of masculinity may be singled out for demeaning, hostile and even violent sexual conduct, usually by other men, but sometimes by women.

In contrast to male-to-male $\mathrm{SH}$, the harassment of men by women manifested very differently. While we do not suggest that female-perpetrated SH against men was trivial, the conduct that was reported was more likely than that in other groups to be non-physical only, and to involve behaviours that were arguably less serious. Furthermore, male complainants alleging SH by women were far less likely to report serious impacts on their non-work relationships, suggesting SH by women was perceived as less personally damaging. However, negative work-related outcomes were at least as frequent in the female-to-male 
group as in other groups. This finding refutes previous work suggesting that males who are targeted by women experience less serious job-related consequences than males targeted by other men (Dubois et al., 1998; Stockdale et al., 1999; Street et al., 2007) and hence, indicates that female-to-male SH can be as disruptive to employment relationships as manifestations involving other sex dyads.

Lower rates of settlement and more problematic complaints pathways for the female-tomale complaints suggests that complaints of atypical SH may be more difficult to resolve, at least externally to the workplace, and/or may be less well understood by anti-discrimination agencies. While SH is legally expansive, in that it is inclusive of a range of inappropriate sexual conduct (AHRC, 2011), in practice, classic SH may be used as a yardstick by those involved in resolving a complaint, with atypical manifestations being seen as more transgressive or unexpected, and therefore more difficult to settle.

Comparisons of prevalence statistics versus numbers of formal complaints suggest that men, who have been shown to be less likely than women to name sexually harassing behaviours as SH (Nielsen et al., 2010), may also be less willing to engage with the external processes involved in lodging a formal complaint. For example, in a representative Australian prevalence survey (AHRC 2008) conducted around the same time as the data collection for this study, atypical SH constituted nearly half of all reported incidences in the community, compared to only one in five of the formal complaints reported to equal opportunity commissions. When considering the three atypical groups in particular, while the proportion of female-to-female SH in the prevalence study and formal complaints data was very similar (6 percent), the proportion of male-initiated formal complaints (one in six) was much lower than the proportion of men in the community sample (one in three) who indicated that they had experienced SH in their workplace (AHRC, 2008). These comparisons provide strong evidence that men are markedly less likely than women to make a formal complaint of SH 
outside the workplace, regardless of whether they allege harassment by men or women. Men's reticence to report SH may be for the same reasons they are targeted; because doing so calls attention to their nonconformity to a traditional masculine stereotype (O’Leary-Kelly et al., 2000; Stockdale, 1998). Moreover, a focus on the 'sexual' in SH laws (Thornton, 2002) may also work to minimise the visibility of sex-based harassment as a legal harm, especially where the alleged conduct involves generalised, non-physical harassment, which commonly characterises female-to-male complaints.

Although our analysis of four sex-based manifestations of workplace SH revealed important distinctions between groups, it is important to acknowledge that there were also similarities between groups, as well as variations in the details of individual complaints within groups. With respect to similarities, the study showed that $\mathrm{SH}$, regardless of the sex of the complainant or the alleged harasser/s, is under-reported compared to its prevalence; characterised by a wide range of intimidating, offensive physical and non-physical conduct; and causes significant psychological and workplace damage. These similarities suggest that while the implementation of some workplace $\mathrm{SH}$ policies may need to be group specific, for example in providing safe, supportive complaints mechanisms for men especially to report the problem, many of the organisational prevention and response strategies outlined in previous work (e.g., McCann, 2005) are likely to be effective in preventing and addressing SH in all its forms.

\section{Conclusions}

Our analysis of atypical forms of SH extends theoretical insights from wide ranging gender, work and organisations scholarship that the 'doing of gender' occurs within a normatively masculine organisational context (Cleveland et al. 2005; Pullen and Knights 2007; Powell et 
al. 2009). In both classic and atypical forms of SH, the 'doing' of SH functions as a form of patrolling the 'gender borders' of the particular norm of masculinity that dominates in that specific workplace, tolerating and reinforcing such conduct in socially acceptable ways (Cleveland et al. 2005; Fitzgerald et al., 1997). In certain contexts, women may be encouraged or sanctioned to perform as ‘honorary men’ (Powell et al. 2009: 413); adopting sexualised banter in order to assert their status, maintain authority and 'fit in' with the dominant gender culture (Powell et al. 2012; Pullen and Knights 2007; Wajcman, 1998). This was clearly illustrated in the female-to-female complaints examined for the study, which were characterised by non-physical conduct such as sexualised language from a female supervisor towards a female subordinate, to a greater extent than the male perpetrated examples.

The propensity for women to perform as honorary men can also be explained in some of the female-to-male complaints where women denigrated men with homophobic slurs. This aligns with Epstein's (1997) notion of heterosexism, where men are punished for deviating from prescribed heterosexual norms and gender roles. Such conduct was however most frequent in the male-to-male complaints where male targets were subjected to antigay biases and gender hostility (Epstein, 1997; Knights and Tulberg, 2011; Prior and Whalen, 1997). At the same time, the relatively infrequent and more ambiguous nature of $\mathrm{SH}$ involving male targets appeared to pose challenges in reporting and successfully engaging with legal processes.

The performance of masculinity and femininity in organisations may not necessarily align with the gender ratios of employees across the organisation, as implied in sex role spillover theory. As the complaints examined for this study show, SH occurs across a wide variety of workplaces with very different gender proportions, both horizontally (number of women/men in occupational groupings) and vertically (number of women/men at different 
hierarchical levels). Nor can it be assumed that an entire organisation, especially if a large one, can be characterised in a consistent way throughout in terms of the propensity for $\mathrm{SH}$ to occur. While organisational-level phenomena such as $\mathrm{SH}$ policies and training and effective senior leadership may have an impact on the prevalence of SH across different organisational sites, departments or teams (McDonald, Charlesworth and Graham, 2014), dominant masculinity norms may also vary in these different contexts, ranging from wielding managerial power, to bravado and taking physical risks, to sexually harassing behaviours such as denigration with homosexual epithets (Ely and Myerson, 2010; Knights and Tullberg, 2012). For example, in the UK banking sector McDowell points to the dominance of a 'swinging dick' version of masculinity in dealing rooms, with a more polite patriarchy prevailing in executive suites (McDowell, 1997). Indeed, in all dyads examined for this study, the context-dependent dynamics between SH targets and their co-workers and frontline managers with whom they worked on a day to day basis were central to the nature and duration of the conduct itself, and to subsequent responses once the SH became evident. In summary, we argue that a focus on organisational and work group level dynamics offers more comprehensive and nuanced explanatory potential for both typical and atypical forms of SH than notions of attraction, occupation sex ratios/roles, or exploitative or coercive power. Indeed, variations in individual SH complaints within the different groups examined illustrates the difficulty in attributing specific yet consistent explanations for different manifestations based on sex dyad. The study does however, redress the lack of empirical attention to, and community recognition of, atypical SH, including by the media which tends to emphasise salacious sexual conduct by high profile men against female subordinates (McDonald and Charlesworth, 2013). In this way, the study contributes to a more nuanced characterisation of SH that may be useful for guiding individual responses and organisational 
practices that more effectively prevent and redress SH in its various guises (Dubois et al., 1998), and for informing future research and changing public discourse. 


\section{Endnotes}

${ }^{1}$ In some Australian states and territories they are referred to as anti-discrimination commissions, but their functions are similar

${ }^{2}$ See Charlesworth, McDonald, Worley, Graham and Lykhina (2012) for detailed data collection methods. 


\section{References}

Australian Human Rights Commission. (2012) Working Without Fear: Results of the Sexual Harassment National Telephone Survey. Sydney, Australia: AHRC.

Australian Human Rights Commission [AHRC]. (2011) Federal Law On Line 2011

Available at http://www.humanrights.gov.au/our-work/legal/federal-discrimination$\underline{\text { law-2011 }}$

Aggarwal A, Gupta M (2000) Sexual Harassment in the Workplace. 3rd Edn. Vancouver, BC: Butterworths.

Bargh JA, Raymond P (1995) The naive misuse of power: Nonconscious sources of sexual harassment. Journal of Social Issues 51(1): 85.

Berdahl J (2007) The sexual harassment of uppity women. Journal of Applied Psychology 92: 425-437.

Berdahl JL, Magley VJ, and Waldo CR (1996) The sexual harassment of men: Exploring the concept with theory and data. Psychology of Women Quarterly 20: 527-547.

Bergman M, and Henning J (2008) Sex and ethnicity as moderators in the sexual harassment phenomenon: A revision and test of Fitzgerald et al. (1994). Journal of Occupational Health Psychology 13: 152-167.

Brant C, Too Y (1994) Rethinking Sexual Harassment. London: Pluto Press.

Butler J (1990) Gender Trouble: Feminism and the Subversion of Identity. New York: Routledge.

Charlesworth S, McDonald P, Worley A, Graham T, and Lykhina A (2012). Formal complaints of workplace sexual harassment lodged with Australian Human Rights and Equal Opportunity Commissions 1 July - 31 December 2009. Adelaide Australia: University of South Australia. 
Cleveland J, Vescio T, and Barnes-Farrell J (2005) Gender discrimination in organizations. In Dipboye R and Colella A (eds) Discrimination at Work. The Psychological and Organizational Bases. Mahwah, NJ: Lawrence Erlbaum Associates, 425-462.

DeSouza ER, Solberg J (2004) Women's and men's reactions to man-to-man sexual harassment: Does the sexual orientation of the victim matter? Sex Roles 50(9/10): 623639.

Dubois CL, Knapp DE, Faley RH, and Kustis GA (1998) An empirical examination of same and other gender sexual harassment in the workplace. Sex Roles 39(9/10): 731-749.

Ely, RJ, Meyerson, DE (2010) An organizational approach to undoing gender: The unlikely case of offshore oil platforms. Research in Organizational Behavior, 30: 3-34.

Epstein D (1997) Keeping them in their place: hetero/sexist harassment, gender and the enforcement of heterosexuality. In Thomas A and Kitzinger C (eds) Sexual Harassment: Contemporary Feminist Perspectives. Buckingham: Open University Press, 158.

Equal Employment Opportunity Commission (EEOC) (2005) Trends in Harassment Charges Filed with the EEOC. Available at http://www.eeoc.gov/stats/harassment.html

Fitzgerald L, Drasgow F, Hulin C, Gelfand M, and Magley V (1997) Antecedents and consequences of sexual harassment in organizations: A test of an integrated model. Journal of Applied Psychology 82: 578-589.

Fitzgerald L, Drasgow F, and Magley V (1999) Sexual harassment in the armed forces: A test of an integrated model. Military Psychology 11: 329-343. 
Fitzgerald LF, Gelfand MJ, and Drasgow F (1995) Measuring sexual harassment: Theoretical and psychometric advances. Basic and Applied Social Psychology 17(4): 425-445.

Foote W, and Goodman-Delahunty J (2005) Evaluating Sexual Harassment. Psychological, Social and Legal Considerations in Forensic Examinations. Washington, DC: American Psychological Association.

Forell CA (2005) The Meaning of Equality: Sexual Harassment, Stalking, and Provocation in Canada, Australia, and the United States. Thomas Jefferson Law Review, 28: 151-166. Gutek B (1985) Sex and the workplace. San Francisco: Jossey-Bass.

Handy J (2006) Sexual harassment in small-town New Zealand: A qualitative study of three contrasting organizations. Gender, Work and Organization 13: 1-24.

Illies R, Hauserman N, Schwochau S, and Stibal J (2003) Reported incidence rates of workrelated sexual harassment in the US: Using meta-analysis to explain reported rate disparities. Personnel Psychology 56: 607-618.

Knights D, Tullberg M (2012) Managing masculinity/mismanaging the corporation. Organization, 19(4), 385-404.

Lee D (2000) Hegemonic masculinity and male feminisation: The sexual harassment of men at work. Journal of Gender Studies 9(2): 141-155.

MacKinnon C (1979) The Sexual Harassment of Working Women. New Haven, CT: Yale University Press.

Madera J, Podratz K, King E, and Hebl M (2007) Schematic responses to sexual harassment complainants: The influence of gender and physical attractiveness. Sex Roles 56: 223230.

Magley VJ, Waldo CR, Drasgow F, and Fitzgerald LF (1999) The impact of sexual harassment on military personnel: Is it the same for men and women? Military Psychology 11(3): 282-302. 
McCann D (2005) Sexual Harassment at Work: National and International Responses.

Geneva: International Labour Office.

McDonald P (2012) Workplace sexual harassment 30 years on: A review of the literature. International Journal of Management Reviews 14(1): 1-17.

McDonald P and Charlesworth S (2013) Framing sexual harassment through media representations. Women’s Studies International Forum 37(2): 95-103.

McDonald P, Charlesworth S, and Graham T (2014). Developing a framework of effective prevention and response strategies in workplace sexual harassment. Asia Pacific Journal of Human Resources, published online May 2014. Available at http://authorservices.wiley.com/bauthor/onlineLibraryTPS.asp?DOI=10.1111/17447941.12046\&ArticleID=1311077

McDowell L (1997) Capital culture: gender at work in the city. Oxford: Blackwell.

Nielsen MB, Bjorkelo B, Notelaers G, and Einarsen S (2010) Sexual harassment: Prevalence, outcomes, and gender differences assessed by three different estimation methods. Journal of Aggression, Maltreatment \& Trauma 19: 252-274.

O'Leary-Kelly AM, Paetzold RL, and Griffin RW (2000) Sexual harassment as aggressive behavior: an actor-based perspective. Academy of Management Review 25: 372-388.

Powell A., Bagilhole B, and Dainty A (2009) How women engineers do and undo gender: consequences for gender equality. Gender, Work \& Organization 16(4): 411-428.

Pullen A, Knights D (2007) Editorial: undoing gender: organizing and disorganizing performance. Gender, Work \& Organization 14(6): 505-511.

Pryor J, Whalen N (1997) A typology of sexual harassment: Characteristics of harassers and the social circumstances under which sexual harassment occurs. In O’Donohue W (ed.) Sexual Harassment: Theory, Research and Treatment. Needham Heights, MA: Allyn and Bacon, 129-151. 
Samuels H (2003) Sexual harassment in the workplace: a feminist analysis of recent developments in the UK. Women's Studies International Forum 26: 467-482.

Skinner KM, Kressin N, Frayne S, Tripp TJ, Hankin CS, Miller DR, et al. (2000) The prevalence of military sexual assault among female veterans’ administration outpatients. Journal of Interpersonal Violence 15: 291-310.

Stockdale M (1998) The direct and moderating influences of sexual harassment pervasiveness, coping strategies and gender on work-related outcomes. Psychology of Women Quarterly 22: 379-392.

Stockdale M, Visio M, and Batra L (1999) The sexual harassment of men: Evidence for a broader theory of sexual harassment and sex discrimination. Psychology, Public Policy and Law 5: 630-664.

Street AE, Gradus JL, and Stafford J (2007) Gender differences in experiences of sexual harassment: data from a male-dominated environment. Journal of Consulting and Clinical Psychology 75(3): 464-474.

Thornton M (2002) Sexual harassment losing sight of sex discrimination. Melbourne University Law Review 26: 422-444.

Vogt D, Bruce T, Street A, and Stafford J (2007) Attitudes toward women and tolerance for sexual harassment among reservists. Violence against Women 13: 879-900.

Wajcman J (1998) Managing like a man: Women and men in corporate management. Cambridge: Polity Press.

Waldo CR, Berdahl JL, and Fitzgerald LF (1998) Are men sexually harassed? If so, by whom? Law and Human Behavior 22(1): 59-79.

Wayne JH, Riordan CM, and Thomas KM (2001) Is all sexual harassment viewed the same? Mock juror decisions in same- and cross-gender cases Journal of Applied Psychology 86(2): 179-187. 
Wear D, Aultman J, and Borgers N (2007) Retheorising sexual harassment in medical education: Women students’ perceptions at five US medical schools. Teaching and Learning in Medicine 19: 20-29.

Welsh S (1999) Gender and sexual harassment. Annual Review of Sociology 25: 169-190.

Willness CR, Steel P, and Lee K (2007) A meta-analysis of the antecedents and consequences of workplace sexual harassment. Personnel Psychology 60(1): 127-162.

Yagil D (2008) When the customer is wrong: A review of research on aggression and sexual harassment in service encounters. Aggression and Violent Behavior 13(2): 141-152.

Zalk S (1990) Men in the academy: A psychological profile of harassment. In Paludi M (ed.) Ivory Power: Sexual Harassment on Campus. Albany, NY: State University of New York Press, 141-175. 
Acknowledgements

This paper draws on research funded by an Australian Research Council Discovery grant (DP1093442).

Bios

Paula McDonald is Professor and ARC Future Research Fellow in the School of Management at the Queensland University of Technology in Brisbane, Australia.

Sara Charlesworth is Professor and ARC Future Research Fellow in the School of Management at RMIT University in Melbourne, Australia. 
Table 1. Complainant-harasser groups in SH complaints

\begin{tabular}{|l|l|l|}
\hline \multicolumn{1}{|c|}{ Complainant-harasser groups } & & \multicolumn{1}{|c|}{ N } \\
\hline Female complainant, Male harasser & 221 & 78.4 \\
\hline Female complainant, Female harasser & 16 & 5.7 \\
\hline Male complainant, Female harasser & 14 & 5.0 \\
\hline Male complainant, Male harasser & 31 & 11.0 \\
\hline Total & & 100 \\
\hline
\end{tabular}


Table 2. Direction of alleged SH

\begin{tabular}{|c|c|c|c|c|c|c|c|c|}
\hline Grouping & \multicolumn{2}{|c|}{ Male-to-female } & \multicolumn{2}{|c|}{$\begin{array}{l}\text { Female-to- } \\
\text { female }\end{array}$} & \multicolumn{2}{|c|}{ Female-to-male } & \multicolumn{2}{|c|}{ Male-to-male } \\
\hline Direction & $\mathrm{N}$ & $\%$ & $\mathrm{~N}$ & $\%$ & $\mathrm{~N}$ & $\%$ & $\mathrm{~N}$ & $\%$ \\
\hline $\begin{array}{l}\text { Supervisor- } \\
\text { subordinate }\end{array}$ & 160 & 74.1 & 15 & 93.8 & 10 & 71.4 & 20 & 66.7 \\
\hline Peer/co-worker & 45 & 20.8 & 1 & 6.3 & 4 & 28.6 & 8 & 26.7 \\
\hline $\begin{array}{l}\text { Friend/family } \\
\text { member of } \\
\text { manager }\end{array}$ & 1 & 0.5 & 0 & 0 & 0 & 0 & 2 & 6.7 \\
\hline $\begin{array}{l}\text { External } \\
\text { contractor }\end{array}$ & 10 & 4.6 & 0 & 0 & 0 & 0 & 0 & 0 \\
\hline Total* & 216 & 100 & 16 & 100 & 14 & 100 & 30 & 100 \\
\hline
\end{tabular}

*Numbers in total row may be different to group numbers due to missing data 
Table 3. Physical and non-physical SH alleged

\begin{tabular}{|c|c|c|c|c|c|c|c|c|}
\hline Grouping & \multicolumn{2}{|c|}{ Male-to-female } & \multicolumn{2}{|c|}{$\begin{array}{c}\text { Female-to- } \\
\text { female }\end{array}$} & \multicolumn{2}{|c|}{ Female-to-male } & \multicolumn{2}{|c|}{ Male-to-male } \\
\hline Type of SH & $\mathrm{N}$ & $\%$ & $\mathrm{~N}$ & $\%$ & $\mathrm{~N}$ & $\%$ & $\mathrm{~N}$ & $\%$ \\
\hline $\begin{array}{l}\text { Non-physical SH } \\
\text { only }\end{array}$ & 102 & 46.2 & 11 & 68.8 & 8 & 57.1 & 15 & 50.0 \\
\hline Physical SH only & 14 & 6.3 & 1 & 6.3 & 3 & 21.4 & 4 & 13.3 \\
\hline $\begin{array}{l}\text { Both physical and } \\
\text { non-physical SH }\end{array}$ & 105 & 47.5 & 4 & 25.0 & 3 & 21.4 & 11 & 35.5 \\
\hline Total* & 221 & 100 & 16 & 100 & 14 & 100 & 30 & 100 \\
\hline
\end{tabular}


Table 4. Reported work and non-work consequences of sexual harassment for complainants

\begin{tabular}{|c|c|c|c|c|c|c|c|c|}
\hline Consequences* & \multicolumn{2}{|c|}{$\begin{array}{l}\text { Male-to- } \\
\text { female }\end{array}$} & \multicolumn{2}{|c|}{$\begin{array}{l}\text { Female-to- } \\
\text { female }\end{array}$} & \multicolumn{2}{|c|}{$\begin{array}{l}\text { Female-to- } \\
\text { male }\end{array}$} & \multicolumn{2}{|c|}{ Male-to-male } \\
\hline Work-related & $\mathrm{N}$ & $\%$ & $\mathrm{~N}$ & $\%$ & $\mathrm{~N}$ & $\%$ & $\mathrm{~N}$ & $\%$ \\
\hline $\begin{array}{l}\text { Changes to employment } \\
\text { terms/conditions }\end{array}$ & 64 & 29.0 & 1 & 6.3 & 3 & 21.4 & 6 & 19.4 \\
\hline $\begin{array}{l}\text { Denied/limited access to } \\
\text { benefits or opportunities }\end{array}$ & 16 & 7.2 & 1 & 6.3 & 1 & 7.1 & 2 & 6.5 \\
\hline Dismissal/redundancy & 54 & 24.4 & 3 & 18.8 & 7 & 50.0 & 3 & 9.7 \\
\hline Forced resignation & 81 & 36.7 & 6 & 37.5 & 3 & 21.4 & 6 & 19.4 \\
\hline $\begin{array}{l}\text { Workers' compensation, } \\
\text { sick or stress leave }\end{array}$ & 37 & 16.7 & 0 & 0 & 0 & 0 & 5 & 16.1 \\
\hline $\begin{array}{l}\text { Negative impact on } \\
\text { workplace relationships }\end{array}$ & 85 & 38.5 & 9 & 56.3 & 2 & 14.3 & 16 & 51.6 \\
\hline \multicolumn{9}{|l|}{ Non work-related } \\
\hline $\begin{array}{l}\text { Impact on relationships } \\
\text { with partner/family/friends }\end{array}$ & 55 & 24.9 & 7 & 43.8 & 2 & 14.3 & 8 & 25.8 \\
\hline Individual offence/distress & 178 & 80.9 & 15 & 93.8 & 6 & 42.9 & 26 & 83.9 \\
\hline Impact on health/wellbeing & 164 & 74.5 & 10 & 62.5 & 5 & 35.7 & 21 & 67.7 \\
\hline Financial hardship & 57 & 25.9 & 5 & 31.3 & 1 & 7.1 & 2 & 6.5 \\
\hline
\end{tabular}

*Multiple responses were possible 
Table 5. Relationship with employer at time of complaint

\begin{tabular}{|c|c|c|c|c|c|c|c|c|}
\hline Grouping & \multicolumn{2}{|c|}{ Male-to-female } & \multicolumn{2}{|c|}{$\begin{array}{c}\text { Female-to- } \\
\text { female }\end{array}$} & \multicolumn{2}{|c|}{ Female-to-male } & \multicolumn{2}{|c|}{ Male-to-male } \\
\hline Relationship & $\mathrm{N}$ & $\%$ & $\mathrm{~N}$ & $\%$ & $\bar{N}$ & $\%$ & $\mathrm{~N}$ & $\%$ \\
\hline Current employer & 84 & 38.0 & 5 & 31.3 & 4 & 28.6 & 18 & 58.1 \\
\hline Former employer & 134 & 60.6 & 11 & 68.8 & 9 & 64.3 & 13 & 41.9 \\
\hline $\begin{array}{l}\text { Potential } \\
\text { employer }\end{array}$ & 3 & 1.4 & 0 & 0 & 1 & 7.1 & 0 & 0 \\
\hline Total & 221 & 100 & 16 & 100 & 14 & 100 & 31 & 100 \\
\hline
\end{tabular}

